\title{
Indonesian Learning for Autistic Students in Public Elementary School Sumbersari 1 Malang, Indonesia
}

\author{
Tomas Iriyanto \\ Department of Early Childhood Education \\ Universitas Negeri Malang, Indonesia \\ tomasiriyanto@yahoo.com
}

\begin{abstract}
Implementation of learning Indonesian V class for students with autism in inclusive schools SDN Sumbersari 1 Malang. This study aims to describe the implementation of learning Indonesian V class for autistic students ranging from lesson plans, learning, and assessment. The research approach used is a qualitative approach with case study. The presence of researchers in the field as a full observer, without getting involved in learning. The data collection is done by observation, interviews, and documentation. Furthermore, the data were analyzed with data reduction, data, and drawing conclusions. Checking the validity of the findings of research done by extending the presence of the researcher, perseverance observation and triangulation. The subjects were grade teacher, teacher assistant special (GPK), shadow teacher, and students with autism. the results showed that the implementation of Indonesian learning for autistic students performing well despite the class teacher was not guided by the RPP modifications and the number of students with autism in the classroom quite a lot of the number of normal students.
\end{abstract}

Keywords: autistic students, elementary school inclusion

\section{INTRODUCTION}

Education plays a very important in the life of a country which is to ensure the survival of the state and nation. The sustainability of a country relies on the Human Resources (HR) quality. In an effort print quality human resources, the government is trying to improve the education system. One of the educational systems that discussed the current government is the education system for children with special needs from time to time changes in accordance with the view towards the development of children with special needs. In an effort to make the independence of children with special needs education experts have worked to improve the education of children with special needs system of segregated education system to the education system integration.

In the approach to segregation, education for children with special needs do in SLB according to the type of disorder. They are educated separately from other children both in learning and community. Even among them have to part with the family occupying the hostel was offered to him. The aim of education for them is capable society. Seeing this condition is unlikely, so the segregation approach is deemed incompatible with efforts to children's education as a whole. The child is considered successful if the child is able to live with other children in the family, at school and in the community. Therefore, there is another approach in the form of inclusion approach.

Inclusive education is the embodiment of the inclusion approach

seeks to educate children with special needs together other children (normal) to optimize its potential. It is based on the fact that in society there are normal children and children with special needs that cannot be separated as a community. The placement of children in obtaining educational services tailored to the level of deficiencies and needs that child. Therefore, children with special needs should be given opportunities and the same chances to normal children to be educated in inclusive schools nearby.

Educational inclusion as an educational service which the students have the ability heterogeneous and some students need to get a special service according to ability / abnormality of the students. Therefore, learning strategies tailored to the needs and characteristics of students. The teachers are generally not prepared to teach students with special needs, so often experience difficulties when dealing with children with special needs.

SDN Sumbersari 1 Malang is one of the public elementary schools that provide education for children with special needs. This school became one of the pilot inclusive schools in East Java. This is supported by facilities and infrastructure continue to be improved to support the learning process more effective and efficient. Starting from the building into a multi-story building, utilizing old buildings for a specific room / space therapy for students with special needs. In addition to a special room / space therapy for students with special needs, the old building is also used for prayer rooms, library and laboratories. Schools are also trying to expand learning media for students with special needs, such as providing educational games and puzzles.

SDN Sumbersari 1 Malang also has a number of special needs students at most schools among other inclusions in the poor city with 19 students in each class spread. Students with special needs most in a class V student number 54 of them are students with autism. Children with autism are children who have developmental disorders in communication, social interaction and behavior. Most children with autism have problems / disorders in the fields of communications relating to the language. Based on the above exposure, 
researchers interested in conducting research on the implementation of learning Indonesian $\mathrm{V}$ classes for students with autism in inclusive schools SDN Sumbersari 1 Malang.

Inclusive education is one form of educational services it seeks to provide educational services to children with special needs is an integral and humane. Through education, inclusion of children with special needs are educated alongside other children (normal) to optimize their potential. Inclusive education is intended as a "system of education services to include children with special needs learn together with peers in regular schools closest to their homes" (MONE, 2007). Autism is children and adolescents that show defects in social interaction, communication and imagination games before the age of three years (Williams, 2007). With the development disorders, especially in communication and social interaction in autistic children this is an obstacle course for children with autism in the language so that language skills of children with autism need to be developed.

Implementation of learning in inclusive settings need to plan some things (MONE, 2007) are: (a) set a goal to be achieved; (b) planning the management of classes ranging from a classroom setting and organizing students (individuals, groups, pairs, classical) adjusted to the defined goals; (c) plan the organization of materials ranging from setting the main material to be taught, determines the presentation of material enrichment for students who are good at, and determine remedial materials for students who are less intelligent; (d) planning the management of learning activities include the formulation of learning objectives, determining teaching methods, and determine the steps to teach; (e) planned use of learning resources both determine the source of learning materials (e.g. textbooks, supplementary books) or determine the learning resources (eg, globes, photographs, original objects, mock objects, the natural environment, and so on); (f) plan ratings ranging from determining the forms of assessment (e.g. oral test, written test, test actions), make an assessment tool (write matter-because), and determine the follow-up.

Assessment in setting inclusions (MONE, 2007) refers to curriculum development models used are: (1) students with special needs light using full regular curriculum model, then the assessment using a scoring system that applies to regular classes; (2) Special needs students are using the model to the regular curriculum with modifications, then the assessment using a scoring system that has been modified school regularly adjusted to the level of development and needs of students; (3) severe special needs students using the curriculum model PPI, then the judgment is individual and based on the basic abilities of learners.

\section{METHOD}

This research was conducted in the school inclusion class V SDN Sumbersari 1 Malang. This study used a qualitative approach with case study so that researchers can describe clearly and in detail about the implementation of the learning process for students with autism Indonesian Class V. The presence of investigators in this study is complete observer means researchers observed in full without any direct involvement in the learning process.

Sources of data in this study is the classroom teacher, special teacher assistant, shadow teacher, students with autism, learning tools are used, the design of an instructional or written document acquired during the observation and interviews and photos that correspond to the focus of research. Data collection techniques used in qualitative research, namely observation, observation used in this study is participatory observation are classified into passive observation, which is observed only ongoing activities, but does not get involved in it; indepth interviews, types of interviews used in this study is not unstructured interview, the interview is free where researchers only using interview guide outlines the form of the main points of the question in accordance with the focus of research; analysis of documents, to collect documents in accordance with the focus of research.

Steps of data analysis performed in this study include: (1) data reduction or simplification of data, by making selections on all the data have been obtained from the field consisting of the interview process, observation and documentation; (2) exposure or data presentation, by bringing together all the information obtained on each of the focus of research and then made a tentative conclusion that there are some tentative conclusions of each focus of the study; (3) The conclusion, by analyzing the data continuously when researchers were in the field either at the time of collection or at the time of data presentation.

Then test the credibility of, among others, the extension of the presence of investigators conducted to supplement the information relating to the perceived lack of focus of research, as well as more careful in observing the object under study which is expected to reduce errors in receiving information obtained from researchers and informants; perseverance observation is intended to discover the characteristics and elements in a situation that is very relevant to the issue or issues are being searched then focus on the issues examined in detail; and triangulate that data validity checking techniques by utilizing all the information about the issues examined in the field as a comparison of the data obtained.

\section{RESULTS}

Overview class V and students with autism class V SDN Sumbersari 1 Malang, among others: (a) class V had 5 students with special needs, 4 of which are students with autism, 1 students classified as autistic lightweight and 3 students classified as autistic was so in preparing the RPP modification GPK make 1 RPP modifications for 3 autistic students classified as moderate; (b) students with autism have facilities such as therapy rooms; (c) other than the class teacher in the fifth grade teacher also GPK and shadow.

RPP Overview Indonesian modifications for students with autism class V SDN Sumbersari 1 Malang, among others: (a) RPP modifications for students with autism are prepared by GPK; (b) modifications RPP compiled every KD so that it can be used for multiple sessions; (c) modification RPP constituent components the same as for normal students, but there is an additional component indicators, objectives and measures of 
learning activities for students with autism; (d) the annex to the RPP modification simply attach sheets observation and the final assessment, for LKS and about autistic student evaluation is not attached because LKS GPK / classroom teachers make when learning takes place while the matter of evaluation is made when the material has been taught.

Indonesian overview of the implementation of learning for students with autism, among others: (a) the implementation of learning for students with autism carried out by the class teacher; (b) the most dominant class teachers who work with students with autism not GPK; (c) RPP guiding classroom teachers to students is the normal RPP compiled by classroom teachers; (d) when the learning takes place in the shadow teacher is allowed to enter the classroom to monitor learning progress of students with autism; (e) classroom teachers to apply the principles of learning according to the specific characteristics of students with autism.

Indonesian picture learning assessment for students with autism, among others: (a) assessment for students with autism most dominant performed by the class teacher is not GPK; (b) the assessment used is classroom based assessment that includes an initial assessment, the assessment process and assessment of results; (c) The initial assessment assessed autistic students' answers when asked questions; (d) the assessment process is the involvement of the student with autism assessed by answering questions and interacting with friends when a group; (e) Assessment is teacher by giving test evaluation form about the modification to the student with autism who do every KD ends; (f) Assessment process and the results are also done by giving the task either individually or in groups such as the making of a work / product after it is exhibited as the award of works / products have been made; (g) the teacher assessment results for students with autism reported in the form of quantitative data is numeric and qualitative form of narrative.

\section{DISCUSSION}

Class V has 20 students, five of which are special needs students consisting of four students with autism and one deaf student all the male sex. Of the four students with autism, autistic students are relatively light 1 and 3 students with autism moderate. This is consistent with the understanding of inclusive education contained in the Ministry of Education (2007) that in the class there are students with special needs learn alongside students normally and in accordance with Permendiknas number 41 (2007) that the requirements of the number of students in implementing learning for primary school is 28 students.

Three students with autism were classified as moderate, namely Heral, Nanda, and Irfan. The characteristics of the most visible of Heral that emotion is less stable because they love hurt themselves with their own hands often biting, attention is still lacking, still less capable of completing tasks independently. As for the signifier and Irfan has characteristics similar emotions that have a rather unstable, sensitive to words or behavior to her friends, concern is still lacking, can carry out activities in the classroom although sometimes not in accordance with the command.

This is in accordance with the characteristics in children with autism, according Sugiarmin (2007) among which failure to respond to the communications of others, difficulty in expressing emotions and understand the feelings of others, and have behavioral patterns unique body movement repetitive annoying the execution of tasks, such as hand flapping, finger flicking, and jumping. In addition to classrooms and facilities therein, for students with autism there is also a special facility in the form of a special room that is used for the therapy room.

This is in accordance with the Ministry of Education (2007) in setting the inclusion of things that need to be considered include teaching equipment to manage effectively and efficiently. Class V not only has the class teacher but also a special assistant teachers (GPK) and shadow teacher. This is consistent with the explanation contained in the Ministry of Education (2007) that the educators in inclusive schools consist of classroom teachers, subject teachers and teacher assistant special. As for the shadow teacher only designation of inclusive schools for students with special needs assistant.

Lesson plan modifications Indonesian for autistic students in class $\mathrm{V}$ is a plan containing measures of learning activities that are prepared independently by GPK in $1 \mathrm{KD}$ for several meetings. In RPP modification of its components together with the RPP for normal students, but there is an additional component indicators, objectives and measures of learning activities for students with autism.

This is consistent with the explanation Astuti (2011) lesson plan for students with autism is a lesson plan that has been modified from activities introduction, core, and the cover and in accordance with the explanation Akbar (2010) states that the RPP is a lesson plan short term created by teachers about what activities are carried out in the learning process. Preparation of student activity sheet (BLM) and the evaluation questions were not attached because GPK / teachers create their own questions during the learning takes place in accordance with the ability of students with autism. This is in accordance with the Ministerial Regulation number 41 (2007) that the attachment is not included in the RPP component so it's up to the teachers attach LKS and test evaluation or not. However, when the worksheets and teacher evaluation questions attached / GPK really prepare worksheets and evaluation questions for students with autism.

Implementation of Indonesian learning for autistic students carried out by the class teacher and guided by GPK. However, because GPK not always be in class then replace classroom teachers GPK role in guiding students with autism in the classroom. This is not in accordance with the opinion Astuti (2011) on the implementation of learning that the inclusion settings, both teachers, classroom teachers and GPK should cooperate with each other while in the classroom so that learning is more effective and maximum. In every time you make Indonesian learning for autistic students fifth grade teacher guided by the RPP for normal students not RPP modification. This is not in accordance with the 
explanation in his book entitled Astuti AJEL school (2011) that the implementation of learning in inclusive settings is an implementation of the RPP has been modified from the preliminary activities, the core and the cover. Although, without modification RPP classroom teachers can do for students learning Indonesian autism well.

Learning Indonesian teacher for autistic students to apply the principles in accordance with the specific learning characteristics of students with autism. Special principles applied include demonstration of the principle, the principle of repetition, the principle of love. This is consistent with the explanation contained in the Ministry of Education (2007) that the teacher in the classroom inclusion in addition to applying the general principles of learning should also implement the principles of special learning needs and characteristics of students with special needs.

Implementation of Indonesian assessment for students with autism are classroom-based assessment which includes initial assessment, process assessment and final assessment. It fit with the notion classroom assessments contained in the Ministry of Education (2007) that classroom assessment is a form of teachers activities associated with making decisions about the competence or the achievement of learning outcomes of students during the lesson. Assessment process and the results are also done by giving the task either individually or in groups is usually in the form of the creation of a work / product. After the assessment, the task of a work / products on display as the award of works / products have been made.

Its accordance with the kinds of classroom assessments contained in the Ministry of Education (2007) that classroom assessments carried out through various methods, such as written tests, performance assessments of learners through a collection of work / work of students (portfolio), product assessment to assessment techniques different. When students with autism scored below SKM held remedy.

This is consistent with the explanation contained in the Ministry of Education (2007) about the usefulness of classroom assessments of which are used for program improvement (remedial) for learners whose achievements under the thoroughness predetermined limit. The assessment results for students with autism in the form of quantitative and qualitative data. This is in accordance with the form of a progress report of learners in setting inclusions contained in the Ministry of Education (2007: 48) that the assessment results are presented in quantitative and qualitative data so that the rate of progress of learners easily readable and understandable by parents or interested parties (stakeholder) others.

\section{CONCLUSION}

Based on the findings that have been described can be concluded that: (1) Educational inclusion besides there are also classroom teachers GPK and shadow teacher to serve students with special needs who are in the classroom. In addition, for students with special needs also have facilities such as therapy rooms are used when acting autistic students in the classroom; (2) The implementation plans Indonesian learning for autistic students compiled independently by GPK in $1 \mathrm{KD}$ for several meetings quite good. Although, as the operational measures for students with autism still be in one column with normal students; (3) Implementation of Indonesian learning for autistic students conducted by classroom teachers performing well, even though the teacher guided by the RPP for normal students and the number of students with autism as much as 5 students from 20 normal students; (4) The ratings Indonesian for students with autism performing well through based assessment class includes initial assessment, the assessment process and the final assessment, though the ratings of the most dominant performed by the class teacher, and the assessment results for students with autism reported in the form of quantitative data in the form of numbers and qualitative narrative.

\section{REFERENCES}

[1] Curriculum and Learning Social Science (IPS), Yogyakarta: Cipta Media.

[2] Astuti, Idayu. 2012. Effective Strategy for Managing Educational Inclusion. Malang: UM PRESS.

[3] Astuti, Idayu and Walentiningsih, Olim. AJEL 2011. Inclusion School. Bayumedia: Malang.

[4] Director General of Primary and Secondary Education management. 2008. Development of Lesson Plan, Jakarta: Ministry of National Education.

[5] Director General of Primary and Secondary Education management. 2007. General Guidelines for the Implementation of Inclusive Education, Jakarta: Ministry of National Education.

[6] Director General of Primary and Secondary Education management. 2007. Special Implementation Guidelines for Inclusive Education (Teaching and Learning), Jakarta: Ministry of National Education.

[7] Director General of Primary and Secondary Education management. 2007. General Guidelines for the Implementation of Inclusive Education (Procurement and Construction of Teachers). Jakarta: Ministry of National Education

[8] Director General of Primary and Secondary Education management. 2007. Guidelines for the Implementation of Inclusive Education Specials (Rating). Jakarta: Ministry of National Education.

[9] Sugiarmin, Muhammad. 2007. Efforts Helping Autistic Children. Retrieved 23 July 2019, from http://www.depdiknas.go.id/jurnal/anakautis.html.

[10] Republic Act number 20 of 2003 on National Education and the Indonesian government regulations on the administration and compulsory education. 2010. Bandung: Citra Umbara.

[11] Williams, Chris. 2007. How to Live with Autism and Asperger Syndrome. Jakarta: Dian Rakyat 